\title{
PLASMA LH AND FSH DURING DIFFERENT OESTROUS CYCLE CONDITIONS IN MICE
}

\author{
SANDRA M. MURR, I. I. GESCHWIND \\ AND G. E. BRADFORD \\ Department of Animal Science, University of California, \\ Davis, California 95616, U.S.A.
}

(Received 23rd December 1971)

\begin{abstract}
Summary. Concentrations of plasma LH and FSH were measured by radioimmunoassay in four strains of mice maintained in controlled lighting. Gonadotrophin levels in an unselected control line (Line C) were measured under the following conditions: induced cycles; spontaneous cycles; cycles in absence of males and post-partum cycles. In mice with induced cycles, LH reached a mean of about $40 \mathrm{ng} / \mathrm{ml}$ between 16.00 and 17.00 hours of pro-oestrus. Levels of FSH reached a peak of around $2800 \mathrm{ng} / \mathrm{ml}$ about $2 \mathrm{hr}$ later, between 19.00 and 20.00 hours, suggesting that the function of FSH is to stimulate growth of the crop of follicles which will ovulate during the succeeding oestrous cycle. Spontaneously cycling mice of Line $\mathrm{C}$ also had a mean $\mathrm{LH}$ concentration of about $40 \mathrm{ng} / \mathrm{ml}$, but this peak began $1 \mathrm{hr}$ later at 17.00 hours of prooestrus and persisted for about $4 \mathrm{hr}$. No well-defined FSH peak was found. Only two of seventy individually caged females killed during prooestrus had LH or FSH levels greater than the mean di-oestrous levels in induced and spontaneously cycling animals. Within $24 \mathrm{hr}$ of parturition, there was no one time when the majority of mice showed elevated levels of LH or FSH. The timing and magnitude of gonadotrophin release during pro-oestrus of induced cycles in lines successfully selected for small litter size, high embryo survival, and high ovulation rate were the same as for Line $\mathrm{C}$, suggesting that the principal effect of selection was probably to alter the sensitivity of the target organs.
\end{abstract}

\section{INTRODUCTION}

Litter size in polytocous species depends on the number of ova shed during each oestrus (ovulation rate) and the proportion of these surviving to parturition (embryo or prenatal survival). Variations in these parameters among artificially selected strains may depend on different amounts of gonadotrophic hormones produced during the oestrous cycle or during pregnancy. Alternatively, differences between strains may be due to variations in the sensitivity of the target organs to these hormones. Lines of mice successfully selected for high ovulation rate, high embryo survival and small litter size have been used to study whether differences in fecundity have arisen through changes in pituitary 
gonadotrophin secretion, ovarian sensitivity, or both, and the results of some of these studies are reported here.

A necessary prelude to this study was a characterization of LH and FSH patterns in an unselected control line (Line $\mathrm{C}$ ) from the same base population as the three selected lines. Since mouse oestrous cycles are dependent upon olfactory stimuli from the male (see Whitten, 1966), cyclic gonadotrophin levels in Line $\mathrm{C}$ mice were studied under the following oestrous cycle conditions: induced cycles (as described in the next section), spontaneous cycles, cycles in absence of males, and post-partum cycles. Levels of plasma LH and FSH in Line $\mathrm{C}$ were compared with those of the selected lines only under induced oestrous cycle conditions. The levels of LH and FSH in these lines during pregnancy will be reported in a later publication.

\section{MATERIALS AND METHODS}

The selection procedure and response of the lines have been previously reported (Bradford, 1968, 1969, 1971). The present study was carried out on four lines selected for the following reproductive parameters:

1. Line $\mathrm{G}$ : randomly selected control line;

2. Line $\mathrm{CN}^{-}$: small litter size;

3. Line $\mathrm{E}$ : high embryo survival;

4. Line O: high ovulation rate.

Cyclic gonadotrophin patterns were studied in detail in Line $\mathrm{C}$ under the following conditions.

\section{Induced cycles}

Females were synchronized by being grouped fifteen to twenty to a cage (Whitten, 1966) for about 2 weeks before being examined for vaginal smear pattern. Females showing evidence of cycling, i.e. a nucleated and/or cornified cell pattern, were eliminated from the study. Those showing a leucocyte cell pattern were placed in a cage divided by a wire screen into two compartments. Two females were placed on one side and two or three mature males on the other. Vaginal smears were taken daily by saline lavage and examined in unstained wet preparations. The following criteria were used for identification of cycle stage: pro-oestrus: nucleated or nucleated/cornified cells; oestrus: cornified cells; metoestrus: leucocytes and few nucleated or cornified cells; dioestrus: leucocytes or leucocytes/nucleated cells. Females were decapitated and exsanguinated at intervals throughout their first induced cycle.

\section{Spontaneous cycles}

Females were caged adjacent to males as described above, but only those females displaying at least two successive 4- or 5-day vaginal cycles were killed. No distinction was made between the two cycle lengths since an individual female often had both 4- and 5-day cycles.

Cycles in absence of males

Seventy females were housed one to a cage without a male. Although it was 
not possible to eliminate males from the colony completely, they were removed at least $8 \mathrm{ft}$ from the females. Vaginal smears were obtained for three cycles and then the females were killed at intervals during the afternoon of their fourth pro-oestrus.

\section{Post-partum cycles}

Pregnant mice were left with mates and observed for the occurrence of parturition at 20.00 hours on Day 17 (the day of finding a vaginal plug was taken as Day 0). If parturition had not occurred by this time but had occurred by 08.00 hours the following morning, females were killed within $24 \mathrm{hr}$ of delivery, at 3-hr intervals beginning at 08.00 hours.

Females from lines $\mathrm{CN}^{-}, \mathrm{O}$ and $\mathrm{E}$ were compared to Line $\mathrm{G}$ females only under conditions of the induced cycle, since this was the normal procedure used for mating in the colony, i.e. after weaning, young females were grouped several to a cage until the time of pairing with males. Most of the females normally mated within 5 days, with a distinct peak on Day 3 .

All mice were maintained in an environment with controlled lighting (on at 05.00 hours, off at 19.00 hours). Female mice of the four lines were allowed to reach 80 to 100 days of age before experimentation to provide a maximal plasma yield per mouse. Mice were killed by decapitation and their blood was collected through heparinized funnels into glass tubes. The total blood from an individual was necessary to provide enough plasma for duplicate determinations of both hormones. Plasma was separated by centrifugation at $5000 \mathrm{~g}$ at $5^{\circ} \mathrm{C}$ for $20 \mathrm{~min}$. All plasma samples were stored at $-30^{\circ} \mathrm{C}$ and assayed individually within 6 weeks of collection.

Levels of LH and FSH were measured by double antibody radioimmunoassay according to the procedure described by Beamer, Murr \& Geschwind (1972). Hormone concentrations are expressed in terms of ng equivalents NIH-LH-Sl or NIH-FSH-S1/ml plasma. Concentrations lower than the limits of sensitivity, $1.5 \mathrm{ng} / \mathrm{ml}$ for $\mathrm{LH}$ and $225 \mathrm{ng} / \mathrm{ml}$ for $\mathrm{FSH}$, were given those values in calculating means and standard errors.

\section{RESULTS}

\section{Induced cycles}

The concentrations of LH and FSH in the plasma of Line C females during different stages of the induced cycle are shown in Text-fig. 1. Concentrations of LH were $<4 \mathrm{ng} / \mathrm{ml}$ throughout the oestrous cycle except during pro-oestrus. On the morning of pro-oestrus, slightly elevated levels were found $(5.5 \mathrm{ng} / \mathrm{m} \mathrm{l})$. During the afternoon of pro-oestrus, $\mathrm{LH}$ rose to a peak concentration between 16.00 and 17.00 hours. After this time, the LH level began to decrease and by 09.00 hours on the day of oestrus, the level was $<4 \mathrm{ng} / \mathrm{ml}$. The single highest $\mathrm{LH}$ concentration found in this study was $170 \mathrm{ng} / \mathrm{ml}$ at 17.00 hours of prooestrus.

Levels of FSH were highest between 19.00 and 20.00 hours of pro-oestrus with levels increasing and decreasing gradually before and after this period. Of particular interest was the finding that the peak concentration of FSH during pro-oestrus occurred 2 to $3 \mathrm{hr}$ after the peak LH concentration. 


\section{Spontaneous cycles}

Text-figure 2 shows $\mathrm{LH}$ and FSH concentrations in serum obtained from Line $\mathrm{C}$ mice under regular cycling conditions. Between 15.00 and 16.00 hours of pro-oestrus, serum LH began a rapid increase in concentration, the mean

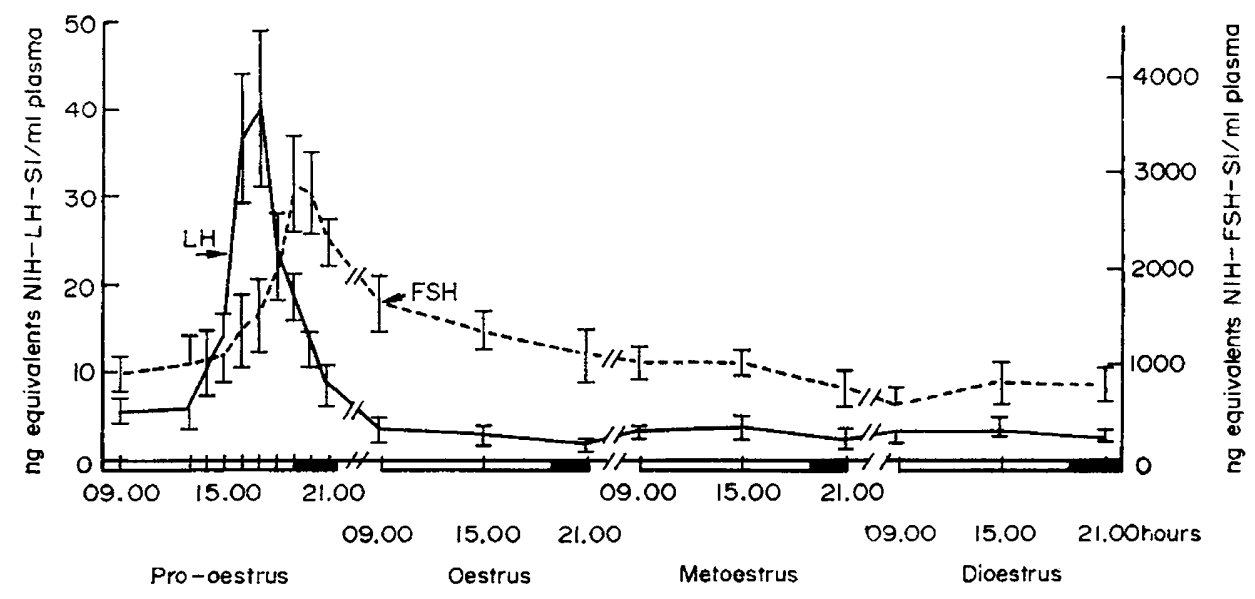

TexT-Fig. 1. Concentrations of LH and FSH, expressed as means and standard errors, in plasma from Line $\mathrm{G}$ mice during an induced oestrous cycle. Black bars indicate dark periods. Each point on the graph represents a minimum of fifteen animals.

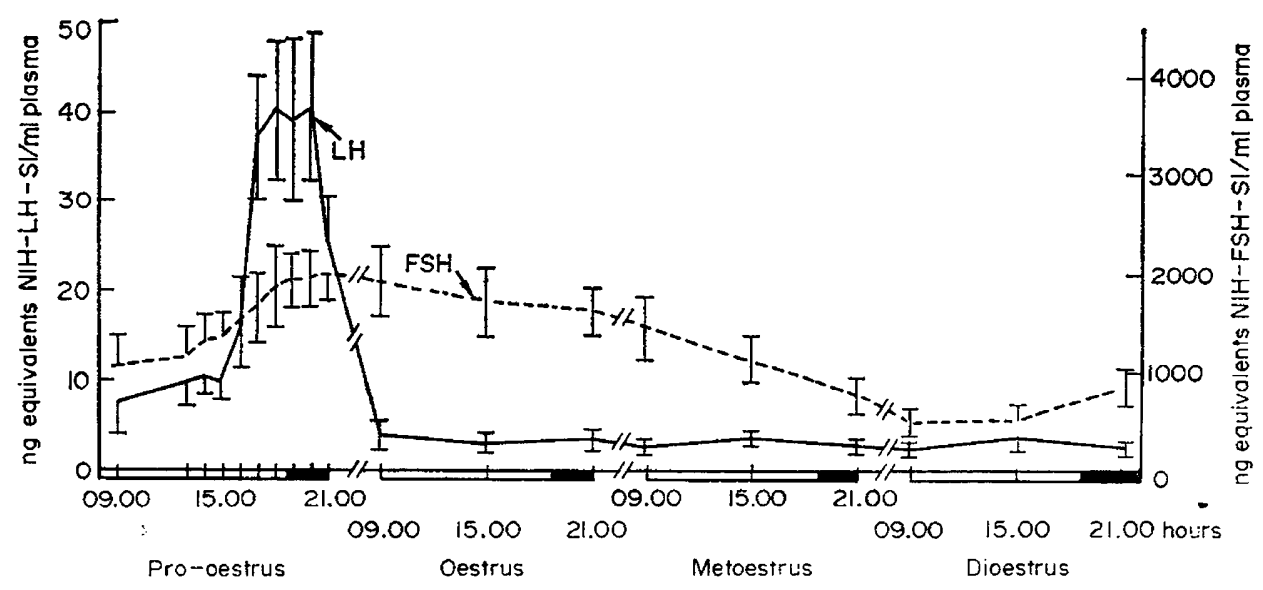

TEXT-FIG. 2. Concentrations of LH and FSH, expressed as means and standard errors, in plasma from spontaneously cycling mice of Line G. Black bars indicate dark periods. Each point on the graph represents a minimum of fifteen animals.

reaching a peak of about $40 \mathrm{ng} / \mathrm{ml}$ around 17.00 hours. This level remained elevated for about $4 \mathrm{hr}$, then decreased to $<4 \mathrm{ng} / \mathrm{ml}$ by the morning of oestrus. Levels of FSH began a gradual increase during the evening of dioestrus but no clear cut peak, as in induced cycles, was found during pro-oestrus. 
Cycles in the absence of males

Table 1 summarizes the mean cycle length of seventy females caged indidividually compared with seventy females in divided cages with males. Females with cycles longer than 4 or 5 days usually had a prolonged dioestrus stage. Ten individually caged females were killed at hourly intervals from 15.00 to 21.00 hours on the afternoon of their fourth pro-oestrus

Only two out of the seventy individually caged females bled during prooestrus had LH or FSH levels greater than the mean dioestrus levels in induced and spontaneously cycling animals. Both of these females were killed at 18.00 hours and had LH values of 15.3 and $29.2 \mathrm{ng} / \mathrm{ml}$ and FSH values of 1575 and $1230 \mathrm{ng} / \mathrm{ml}$. In a preliminary experiment, five cages of mature male mice were inadvertently placed below rows containing thirty individually caged females, six females/row. The six females on the row immediately above the males

Table 1. Comparison of mean cycle length between female mice caged individually and females in divided cages with males

\begin{tabular}{l|c|c|c}
\hline & \multicolumn{3}{|c}{ Mean cycle length (days) } \\
\cline { 2 - 4 } & First & Second & Third \\
\hline 70 females individually caged & $6 \cdot 4 \pm 0 \cdot 36$ & $7 \cdot 3 \pm 0 \cdot 39$ & $5 \cdot 7 \pm 0 \cdot 28$ \\
70 females in divided cages & $4 \cdot 3 \pm 0 \cdot 12$ & $4 \cdot 8 \pm 0 \cdot 16$ & $4 \cdot 6 \pm 0 \cdot 13$ \\
\hline
\end{tabular}

Table 2. Frequency of post-partum female mice with plasma LH and FSH concentrations greater than those found during dioestrus

\begin{tabular}{c|c|c|c|c}
\hline \multirow{2}{*}{$\begin{array}{c}\text { Time } \\
\text { killed } \\
\text { (hours) }\end{array}$} & No. of & \multicolumn{3}{|c}{ No. of females with elevated levels of: } \\
\cline { 2 - 4 } & females & $L H\left(>4 n g / m l^{*}\right)$ & FSH $(>810 \mathrm{ng} / \mathrm{ml} *)$ & $\begin{array}{c}\text { Both } L H \\
\text { and FSH }\end{array}$ \\
\hline 08.00 & 14 & 7 & 5 & 5 \\
11.00 & 14 & 4 & 8 & 4 \\
14.00 & 14 & 5 & 6 & 5 \\
17.00 & 14 & 6 & 7 & 4 \\
20.00 & 14 & 5 & $33(47 \%)$ & $23(33 \%)$ \\
Total & 70 & $27(39 \%)$ & & \\
\hline
\end{tabular}

* Values greater than those found during dioestrus.

showed consistent 4- or 5-day cycles and elevated LH and FSH levels when killed during pro-oestrus. Gonadotrophin levels in these females ranged from $9 \cdot 3$ to $34.7 \mathrm{ng} / \mathrm{ml}$ for $\mathrm{LH}$ and 1115 to $1640 \mathrm{ng} / \mathrm{ml}$ for FSH. On the second row above the males, only one female showed elevated gonadotrophins and regular 4- or 5-day cycles. This female had been killed at 17.00 hours of pro-oestrus and had $29.6 \mathrm{ng} / \mathrm{ml} \mathrm{LH}$ and $1580 \mathrm{ng} / \mathrm{ml} \mathrm{FSH}$.

Post-partum cycles

The frequency of post-partum females having concentrations of $\mathrm{LH}$ and FSH greater than those found at dioestrus is shown in Table 2. Elevated levels 
of both LH and FSH were found in 33\% of the animals. Concentrations of LH ranged from $<4$ to $>96 \mathrm{ng} / \mathrm{ml}$ and of FSH from $<810$ to $>4500 \mathrm{ng} / \mathrm{ml}$.

\section{Induced cycles in Lines ${C \mathcal{N}^{-}}^{-}, O$ and $E$}

The timing and magnitude of gonadotrophin release during pro-oestrus in these lines was found to be the same as for Line $\mathrm{C}$ (Text-fig. 1). Table 3 shows the LH and FSH levels during the times of peak concentration. All values fall within the standard errors found for Line $\mathrm{C}$ and the standard errors for each line overlap those found in the other three lines.

Table 3. Levels of LH and FSH during times of peak concentration during pro-oestrus of induced cycles in four selected strains of mice

\begin{tabular}{l|c|c|c|c|c}
\hline & & \multicolumn{5}{|c}{ Lines } \\
\cline { 3 - 6 } & $\begin{array}{c}\text { Time } \\
\text { (hours) }\end{array}$ & $C$ & $C N^{-}$ & $E$ & $O$ \\
\hline Plasma LH & 16.00 & $37 \cdot 1 \pm 7 \cdot 4$ & $40 \cdot 1 \pm 8 \cdot 3$ & $38 \cdot 6 \pm 5 \cdot 3$ & $39 \cdot 3 \pm 6 \cdot 8$ \\
(ng/ml) & 17.00 & $40 \cdot 4 \pm 9 \cdot 2$ & $38 \cdot 1 \pm 7 \cdot 6$ & $41 \cdot 6 \pm 9 \cdot 7$ & $38 \cdot 7 \pm 7 \cdot 9$ \\
Plasma FSH & 19.00 & $2835 \pm 495$ & $2860 \pm 543$ & $2758 \pm 582$ & $2950 \pm 674$ \\
(ng/ml) & 20.00 & $2760 \pm 450$ & $2700 \pm 434$ & $2690 \pm 402$ & $2860 \pm 629$ \\
\hline
\end{tabular}

\section{DISCUSSION}

\section{Differences among cycle conditions}

Since pro-oestrous animals were randomly assigned times to be bled, maximum LH and FSH concentrations were probably measured in only a few animals. One of the greatest differences between the induced and spontaneously cycling animals was the failure to find a well-defined FSH peak during prooestrus in the spontaneously cycling mice. Since sampling was discontinued after 21.00 hours, it is not known whether an FSH peak occurred after this time. Another difference was the more prolonged surge of LH during pro-oestrus in the spontaneously cycling females. Peak concentrations of $\mathrm{LH}$ in these mice were found over a 4 -hr period beginning at 17.00 hours and lasting until 20.00 hours, while high $\mathrm{LH}$ in mice with induced cycles was only noted over a 2-hr period, so that the total area under the spontaneous cycle LH curve is about twice that found under the induced cycle curve. The peak LH concentration in induced cycling females began at 16.00 hours, $1 \mathrm{hr}$ earlier than in spontaneously cycling females.

Bingel \& Schwartz (1969a) have shown by bioassay that the pituitary LH content at 10.00 hours of pro-oestrus is the same in induced and individually caged female mice. Therefore, differences observed in the duration of LH release in induced and spontaneously cycling mice of the present study are unlikely to be related to pituitary $\mathrm{LH}$ content. The gonadotrophin pattern differences between induced and spontaneously cycling mice during the oestrous cycle in Line $\mathrm{C}$ are similar to those found in the Parkes mouse also studied in this laboratory (W. G. Beamer \& I. I. Geschwind, unpublished observations). The differences in the duration of $\mathrm{LH}$ release in females under the two different 
cycle conditions is no doubt related to the oestrus-inducing pheromone from the male, but how the mechanism affecting duration of $\mathrm{LH}$ release has been altered awaits further investigation.

Among post-partum females, there was no time within $24 \mathrm{hr}$ of delivery when the majority showed an LH or FSH surge. This agrees with the finding of Bingel \& Schwartz (1969c) who suggested that the post-partum oestrous cycle depends more upon time of delivery than upon the light-dark environment.

Whitten (1958) and Bingel \& Schwartz (1969a) found that individually caged females without males exhibit acyclical vaginal smear patterns. Individually caged females of Line $\mathrm{C}$ were also found to have irregular oestrous cycles when compared to Line $\mathrm{C}$ females in the olfactory presence of a male. Only two of seventy individually caged Line C females surveyed from 15.00 to 21.00 hours of pro-oestrus showed elevated levels of LH and FSH. However, females in the olfactory presence of males showed a circumscribed duration of elevated gonadotrophin release during this same time period, indicating that male presence acts to regulate not only the vaginal smear pattern but gonadotrophin release as well.

\section{Comparison with mouse data}

Concentrations of LH and FSH and timing of release from the pituitary during the oestrous cycle of mice maintained on the same lighting schedule as in this study have been previously investigated. Bingel \& Schwartz (1969b), by administering barbital at various times during pro-oestrus, concluded that the critical period for LH release in the mouse is between 17.00 and 21.00 hours. Their results are in good agreement with the timing of LH release in the spontaneously cycling mice of the present study. In the induced cycling mice, however, serum LH levels were at their peak concentration $1 \mathrm{hr}$ earlier, beginning at 16.00 hours.

Desjardins, Chapman \& Bronson (1970) killed mice between 11.00 and 12.30 hours on different days of the cycle, and found the pituitary content of LH highest during dioestrus and lowest during pro-oestrus, coinciding with a threefold increase in plasma LH during pro-oestrus. They were, however, unable to detect changes in either pituitary or plasma FSH levels during the oestrous cycle. This failure to find FSH fluctuations was probably due to the relative insensitivity of the bioassay technique as well as to the early collection of samples.

\section{Comparisons with radioimmunoassay data in the rat and hamster}

The sequence of changes and range of elevated levels of serum LH in the prooestrous mouse are similar to those reported in the rat and golden hamster. Monroe, Rebar, Gay and Midgley (1969) reported that the highest incidence of elevated concentrations of serum LH in pro-oestrous rats occurs between 15.00 and 18.00 hours. Other times for peak serum LH concentrations during the rat pro-oestrus have been reported: between 16.00 and 18.00 hours (Goldman, Kamberi, Siiteri \& Porter, 1969); 17.00 and 18.00 hours (Daane \& Parlow, 1971 ); and 15.00 and 19.00 hours (Piacsek, Schneider \& Gay, 1971). Goldman \& Porter $(1970)$ found that the maximum concentration of $\mathrm{LH}$ in the serum of 
cycling golden hamsters occurred between 15.00 and 16.00 hours on the day of pro-oestrus. In the mouse as in the rat and hamster, the serum LH concentration had returned to basal levels by the morning of oestrus.

Gay, Midgley \& Niswender (1970) were unable to detect differences in the timing of serum LH and FSH surges during the rat pro-oestrus. Daane \& Parlow (1971), however, found the timing of these events in the pro-oestrous rat to be similar to our results for the mouse. They found that serum FSH rose slowly during pro-oestrus, reaching maximum levels between 20.00 and 21.00 hours. This level persisted until 04.00 to 05.00 hours of oestrus then decreased slowly throughout oestrus. Peak levels of serum LH in these rats were observed between 17.00 and 18.00 hours of pro-oestrus or about 2 to $3 \mathrm{hr}$ before the maximum level of serum FSH. In the mouse with induced cycles, maximum levels of serum LH also occurred 2 to $3 \mathrm{hr}$ before the maximum FSH concentration, but the FSH peak was more clearly delineated than in the rat.

Although the exact timing of events may vary slightly according to the species and laboratory, investigators are in agreement that elevated levels of both LH and FSH appear in the plasma before ovulation. However, there is some controversy as to the rôle of FSH in this process. Traditionally, FSH is thought to stimulate follicular development and $\mathrm{LH}$ to induce ovulation. Available evidence in the rat, hamster and mouse has suggested that FSH might not only stimulate follicular growth, but also be concerned in the induction of ovulation as well. The fact that the FSH peak in the mouse clearly comes after the LH peak supports the view that $\mathrm{LH}$ is released to induce already mature follicles to ovulate, while FSH is released to stimulate growth of the crop of follicles which will ovulate during the succeeding oestrous cycle.

\section{Comparisons of selected strains}

Differences in LH and FSH levels during the oestrous cycle in the three selected strains from levels in the control strain might be expected only where differences in ovulation rate occur. Lines $\mathrm{C}_{\text {and }} \mathrm{CN}^{-}$were similar in ovulation rate, normally averaging 10 to 11 , whereas both Lines $\mathrm{E}$ and $\mathrm{O}$ had higher ovulation rates, normally averaging about 13 and 15, respectively. In Line $\mathrm{O}$, this is a reflection of direct response to selection whereas, in Line $\mathrm{E}$, it represents a correlated response (Bradford, 1969). If selection had altered pituitary output rather than ovarian sensitivity to these hormones, differences in the magnitude or duration of elevated gonadotrophin levels would probably have been detectable in the comparisons of Lines $\mathrm{C}$ and $\mathrm{CN}^{-}$with Line $\mathrm{O}$. Since none of the lines differed in duration or magnitude of plasma $\mathrm{LH}$ and FSH peaks (Table 3), it appears that selection had not altered pituitary gonadotrophin output. This suggests that the principal effect of selection was probably to change the sensitivity of the ovaries to LH and/or FSH.

Examples of increased ovulation rate in mice as a result of increased sensitivity of the ovaries to gonadotrophins as well as increased output of gonadotrophins by the pituitaries have been reported. Fowler \& Edwards (1960) attributed changes in ovulation rate resulting from selection for both large and small body size to altered amount of FSH secretion. This altered FSH output was attributed to total pituitary content (larger or smaller size of the pituitary) 
rather than to its unit potency (Edwards, 1962). In response to FSH injections, McLaren (1962) found that changes in ovulation rate following selection for litter size were mainly a result of changes in ovarian sensitivity. Wolfe (1971) reported that mice differing at a single locus, pink-eye dilution, release different numbers of ova in response to exogenous gonadotrophin stimulation. Land \& Falconer (1969) found that alterations in pituitary output as well as in ovarian sensitivity resulted from direct selection for ovulation rate.

From the present work, it is concluded that selection has not altered the timing or the pattern of gonadotrophin release during the oestrous cycle. The principal effect of selection has probably been to alter the sensitivity of the ovaries.

\section{ACKNOWLEDGMENTS}

We are indebted to NIAMD for supplying radioimmunoassay kits for assay of rat $\mathrm{LH}$ and FSH and to Dr W. G. Beamer for his advice in all phases of this investigation. This investigation was supported by NIH grants HD-00394 and RR-06138. S.M.M. was a Health Sciences Advancement Award Postdoctoral Fellow under grant RR-06138.

\section{REFERENCES}

Beamer, W. G., MurR, S. M. \& Geschwind, I. I. (1972) Radioimmunoassay of mouse luteinizing and follicle stimulating hormones. Endocrinology, 90, 823 .

Bingel, A. S. \& Schwartz, N. B. (1969a) Pituitary LH content and reproductive tract changes during the mouse oestrous cycle. F. Reprod. Fert. 19, 215.

Bingel, A. S. \& Schwartz, N. B. (1969b) Timing of LH release and ovulation in the cyclic mouse. 7. Reprod. Fert. 19, 223.

Bingel, A. S. \& Schwartz, N. B. (1969c) Timing of LH release and ovulation in the post partum mouse. F. Reprod. Fert. 19, 231.

BRADFORD, G. E. (1968) Selection for litter size in mice in the presence and absence of gonadotropin treatment. Genetics, Princeton, 58, 283.

BRADFORD, G. E. (1969) Genetic control of ovulation rate and embryo survival in mice. I. Response to selection. Genetics, Princeton, 61, 905.

BRADFORD, G. E. (1971) Growth and reproduction in mice selected for rapid body weight gain. Genetics, Princeton, 69, 499.

DaAne, T. A. \& Parlow, A. F. (1971) Periovulatory patterns of rat serum follicle stimulating hormone and luteinizing hormone during the normal estrous cycle: effects of pentobarbital. Endocrinology, 88, 653.

Desjardins, C., Chapman, V. M. \& Bronson, F. H. (1970) Hypophyseal LH and FSH release and uterine nucleic acid changes during the mouse estrous cycle. Anat. Rec. 167, 465.

Edwaros, R. G. (1962) The size and endocrine activity of the pituitary in mice selected for large or small body size. Genet. Res. 3, 428.

Fowler, R. E. \& Edwaros, R. G. (1960) The fertility of mice selected for large or small body size. Genet. Res. 1, 393.

Gay, V. L., Midgley, A. R., JR \& Niswender, G. D. (1970) Patterns of gonadotrophin secretion associated with ovulation. Fedn Proc. Fedn Am. Socs exp. Biol. 29, 1880.

Goldman, B. D., Kamberi, I. A., Sirteri, P. K. \& Porter, J. C. (1969) Temporal relationship of progestin secretion, LH release and ovulation in rats. Endocrinology, 85, 1137.

Goldman, B. D. \& Porter, J. C. (1970) Serum LH levels in intact and castrated golden hamsters. Endocrinology, 87, 676 .

LAND, R. B. \& Falconer, D. S. (1969) Genetic studies of ovulation rate in the mouse. Genet. Res. 13, 25.

McLaren, A. (1962) The relation between natural fecundity and response to follicle-stimulating hormone. F. Endocr. 25, 137.

Monroe, S. E., Rebar, R. W., Gay, V. L. \& Midgley, A. R., JR (1969) Radioimmunoassay determination of luteinizing hormone during the estrous cycle of the rat. Endocrinology, 85, 720. 
Piacsex, B. E., Schneider, T. C. \& Gay, V. L. (1971) Sequential study of luteinizing hormone (LH) and "progestin" secretion on the afternoon of proestrus in the rat. Endocrinology, 89, 39.

Whitten, W. K. (1958) Modification of the oestrous cycle of the mouse by external stimuli associated with the male. Changes in the oestrous cycle determined by vaginal smears. F. Endocr. 17, 307.

Whrten, W. K. (1966) Pheromones and mammalian reproduction. In: Advances in Reproductive Physiology, Vol. 1, 155. Ed. A. McLaren. Academic Press, New York.

Wolfe, H. G. (1971) Genetic influence on gonadotropic activity in mice. Biol. Reprod. 4, 161. 